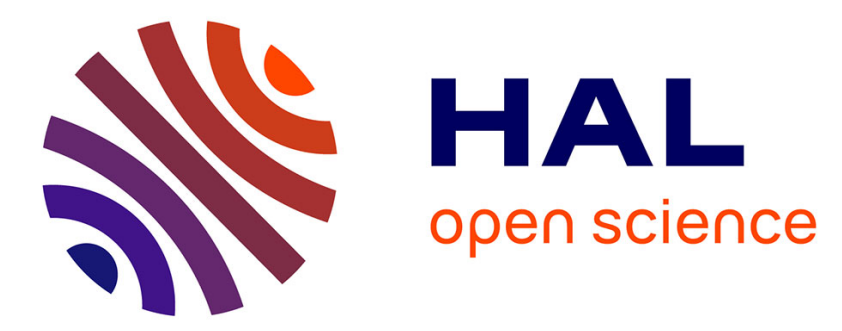

\title{
The axonal guidance factor Netrin-1 as a potential modulator of swine follicular function
}

\author{
G. Basini, C. Cortimiglia, L. Baioni, S. Bussolati, S. Grolli, R. Ramoni, F. \\ Grasselli
}

\section{- To cite this version:}

G. Basini, C. Cortimiglia, L. Baioni, S. Bussolati, S. Grolli, et al.. The axonal guidance factor Netrin1 as a potential modulator of swine follicular function. Molecular and Cellular Endocrinology, 2010, 10.1016/j.mce.2010.08.001 . hal-00639771

\section{HAL Id: hal-00639771 \\ https://hal.science/hal-00639771}

Submitted on 10 Nov 2011

HAL is a multi-disciplinary open access archive for the deposit and dissemination of scientific research documents, whether they are published or not. The documents may come from teaching and research institutions in France or abroad, or from public or private research centers.
L'archive ouverte pluridisciplinaire $\mathbf{H A L}$, est destinée au dépôt et à la diffusion de documents scientifiques de niveau recherche, publiés ou non, émanant des établissements d'enseignement et de recherche français ou étrangers, des laboratoires publics ou privés. 


\section{Accepted Manuscript}

Title: The axonal guidance factor Netrin- 1 as a potential modulator of swine follicular function

Authors: G. Basini, C. Cortimiglia, L. Baioni, S. Bussolati, S.

Grolli, R. Ramoni, F. Grasselli

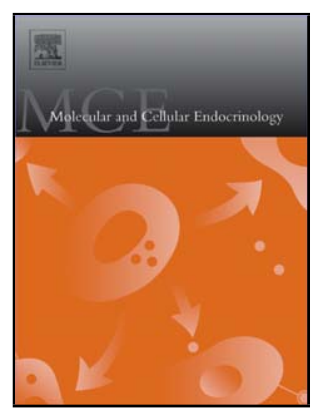

PII:

S0303-7207(10)00415-6

DOI: doi:10.1016/j.mce.2010.08.001

Reference: MCE 7613

To appear in: $\quad$ Molecular and Cellular Endocrinology

Received date: $\quad 31-3-2010$

Revised date: $\quad 2-8-2010$

Accepted date: $\quad 2-8-2010$

Please cite this article as: Basini, G., Cortimiglia, C., Baioni, L., Bussolati, S., Grolli, S., Ramoni, R., Grasselli, F., The axonal guidance factor Netrin-1 as a potential modulator of swine follicular function, Molecular and Cellular Endocrinology (2010), doi:10.1016/j.mce.2010.08.001

This is a PDF file of an unedited manuscript that has been accepted for publication. As a service to our customers we are providing this early version of the manuscript. The manuscript will undergo copyediting, typesetting, and review of the resulting proof before it is published in its final form. Please note that during the production process errors may be discovered which could affect the content, and all legal disclaimers that apply to the journal pertain. 
10 ABSTRACT

11 This study was aimed to improve knowledge about swine ovarian follicular

12 function, paying attention to angiogenesis, since new vessel growth is a

13 fundamental event in ovarian function. In particular, we investigated a potential

14 involvement of netrin-1, a protein known as a guidance axon factor.

15 Firstly, we studied the expression and immunolocalization of netrin-1 in swine

\section{The axonal guidance factor Netrin-1 as a potential modulator of swine follicular function}

\author{
G. Basini $^{1}$, C. Cortimiglia ${ }^{1}$, L. Baioni ${ }^{1}$, S. Bussolati ${ }^{1}$, S. Grolli ${ }^{2}$, R. \\ Ramoni $^{2}$, F. Grasselli ${ }^{1}$ \\ ${ }^{1}$ Sezione di Fisiologia Veterinaria, ${ }^{2}$ Sezione di Biochimica Veterinaria, Dipartimento di Produzioni \\ Animali, Biotecnologie Veterinarie, Qualità e Sicurezza degli Alimenti, Via del Taglio 10, \\ Università degli Studi di Parma, 43126 Parma, Italy
} ovarian follicle and its effect on cultured swine granulosa cell viability and

17 steroidogenesis. Furthermore, aortic endothelial cells were employed to verify a

8 possible netrin-1 effect on angiogenesis.

9 Our data demonstrate the expression and the presence of netrin-1 in swine 0 follicular fluid; in addition, it was shown that netrin-1 inhibits granulosa cell 1 viability and estradiol $17 \beta$ levels while it stimulates progesterone production.

Netrin-1 also inhibits aortic endothelial cell growth in the angiogenesis bioassay. 
1 This effect appears to be mediated by inhibiting Vascular Endothelial Growth

2 Factor and stimulating Nitric Oxide.

3 Therefore, we hypothesize that netrin-1 could be important for follicular

4 function in the swine.

5

6

7

8

9

10

11

12

13

14

15

16

17

18

19

20

21

22

23 


\section{1. I ntroduction}

2 Netrins are a family of highly conserved secreted proteins structurally related to

3 laminins. They were named after the Sanskrit word "netr", which means "one

4 who guides", since they possess guidance cues in axon pathfinding. Recent

5 studies report the involvement of netrins in other developmental process,

6 including the formation of vessels (Cirulli and Yebra 2007). Both neuronal and

7 vascular development require guidance to establish a precise branching pattern

8 and it has been shown that several molecules implicated in axonal navigation

9 have a similar role in regulating vessel sprouting (Larrivée et al., 2009). In

10 particular, netrin-1 has been related to the fine tuning of the angiogenic

11 process and published data demonstrate pro- and anti-angiogenic effects (Park

12 et al., 2004; Larrivée et al., 2007; Bouvrée $K$ et al., 2008; Castets $M$ et al.,

13 2009). Maeda et al. (2008) recently demonstrated that netrin-1 is expressed in

14 swine granulosa cells suggesting that the protein could be involved in the

15 modulation of ovarian follicle function. In particular, netrin-1 could play a role in

16 the regulation of the marked cyclical angiogenesis which takes place in the

17 developing follicle and represents an unvaluable physiological model for the

18 investigation of the molecular events responsible for new vessel growth.

19 On these bases, the present study was undertaken to explore the hypothesis

20 that netrin-1 could act as a physiological modulator of swine follicular function.

21 The expression and the immunolocalization of netrin-1 in swine ovarian follicle

22 were explored and the effect of different protein concentrations on the main

23 parameters of swine granulosa cell function were examined. Moreover, an 
1 angiogenesis bioassay set up in our laboratory (Basini et al., 2008a) was

2 employed to evaluate the effect of netrin-1 on new vessel growth.

3

4 2. Materials and Methods

5

6 All reagents used in this study were obtained from Sigma (St. Louis, MO, USA)

7 unless otherwise specified.

8

$9 \quad 2.1$ Collection of ovaries

10 Swine ovaries were collected at a local slaughterhouse from Large White cross-

11 bred gilts, placed into cold PBS $\left(4^{\circ} \mathrm{C}\right)$ supplemented with penicillin $(500 \mathrm{IU} / \mathrm{ml})$,

12 streptomycin $(500 \mu \mathrm{g} / \mathrm{ml})$ and amphotericin B $(3.75 \mu \mathrm{g} / \mathrm{ml})$, maintained in a

13 freezer bag and transported to the laboratory within $1 \mathrm{~h}$.

\subsection{Netrin-1 in swine ovarian follicle}

\subsubsection{Immunohistochemistry}

18 Ovaries were placed in $10 \%$ buffered formalin and paraffin embedded.

19 Following routine processing, $6 \mu$ m-thick sections were placed on polylisine-

20 treated slides and stained with a polyclonal antiserum raised against a peptide

21 corresponding to 501-604 amino acid sequence of human netrin-1 (Santa Cruz

22 Biotechnology, Santa Cruz, California). Briefly, sections were blocked in $10 \%$

23 normal swine serum for $20 \mathrm{~min}(200 \mu \mathrm{l})$ and then the primary antibody was 
1 applied (250 $\mu$ l of a solution diluted 1:100 in PBS) and incubated overnight at 4

$2{ }^{\circ} \mathrm{C}$. After rinsing in PBS, the slides were incubated for 15 minutes with $200 \mu \mathrm{l}$ of

3 a biotinilated secondary antibody. After three 5-min washes in PBS, $200 \mu \mathrm{l}$ of a

4 solution of streptavidin-peroxidase complex (LSAB®+SYSTEM-HRP, Dako,

5 Glostrup, Denmark) was applied for 15 min. Positive reactions were revealed by

6 aminoethylcarbazole (AEC) (Dako, Glostrup, Denmark). Sections were washed

7 three times for 5 min with PBS and counterstained with Gill's ematoxylin for 2

8 min. Control sections were subjected to the same procedure, except that

9 diluted swine serum replaced the primary antibody.

\section{$11 \quad$ 2.2.2 Western Blotting of follicular fluid protein content}

12 Follicular fluid was collected with a 26-gauge from follicles $>5 \mathrm{~mm}$ (Basini et al.,

$132008 \mathrm{~b})$, centrifuged ( $300 \times \mathrm{g} ; 10 \mathrm{~min}$ ) to separate rapidly the fluid from the cell

14 fraction and refrigerated at $-80 \mathrm{C}^{\circ}$ until assayed. As a positive control, a sample

15 of soluble protein extract from porcine spinal marrow was also prepared. To

16 this aim few grams of tissue were collected from a freshly slaughtered pig and

17 homogenized by Ultra-Turrax (one stroke of 30 seconds at maximum speed) in

$1820 \mathrm{mM} \mathrm{Tris} / \mathrm{HCl} \mathrm{pH} 7.8(1 \mathrm{ml}$ of buffer/gram of tissue). The suspension was

19 centrifuged $(18,000 \mathrm{Xg})$ for 5 minutes and the supernatant was stored $-80 \mathrm{C}^{\circ}$.

20 The protein pattern of follicular fluid and spinal marrow samples were resolved

21 by $10 \%$ sodium dodecyl-sulphate polyacrylamide gel electrophoresis (SDS-

22 PAGE) according to Laemmli (1970). After electrophoresis, the protein bands

23 were transferred onto a ProBlott membrane (Applied Biosystem, Carlsbad, 
1 California) (Towbin et al., 1979) that was blocked with 5\% skimmed dry milk

2 dissolved in $20 \mathrm{~mm}$ Tris / $\mathrm{HCl}$ buffer, $\mathrm{pH} 7.8$ containing $150 \mathrm{~mm} \mathrm{NaCl}$, and

$3 \quad 0.01 \%(\mathrm{w} / \mathrm{v})$ Tween 20 (TTBS). After washing with TTBS the membrane was

4 incubated overnight with an anti-netrin-1 polyclonal antibody (Santa Cruz

5 Biotechnology, Santa Cruz, California) raised in rabbit diluted (1:50) in TTBS

6 containing $1 \%(\mathrm{w} / \mathrm{v})$ skimmed dry milk. After three washes in TTBS the

7 membrane was incubated 45 min. with a solution of a biotinilated anti-rabbit

8 IGg antibody (LSAB ${ }^{\circ}+$ SYSTEM-HRP, Dako, Glostrup, Denmark) diluted 1:5 in

9 TTBS. A solution of complex of streptavidin-peroxidase was then applied for 15

10 min. and positive reactions were revealed by AEC. A replicate SDS-PAGE gel

11 was stained with Comassie blue.

$13 \quad 2.2 .3$ RNA extraction and RT-PCR

14 Follicles $>5 \mathrm{~mm}$ were dissected from the ovaries according to Basini et al.

15 (2010). Each follicle was cut open, granulosa cells were separated by means of

16 using a siliconized Pasteur pipette and centrifuged at $300 \times \mathrm{g}$ for $10 \mathrm{~min}$. Theca

17 tissue was peeled from each follicle using a forceps, deep frozen in liquid

18 nitrogen and powdered in a mortar.

19 Total RNA was extracted using Nucleospin ${ }^{\circledR}$ RNA II (Macherey-Nagel Gmbh,

20 Duren, Germany) according to the manufacturer's instructions. Total RNA was

21 quantified by absorbance at $260 \mathrm{~nm}$ (Gen Quant Pro, Amersham Bioscences,

22 Freiburg, Germany). Total RNA $(2 \mu \mathrm{g})$ was reverse transcribed with Ready-to-

23 Go You Prime First-Strands Beads (Amersham Biosciences, Freiburg, Germany). 
1 Netrin-1 cDNA was PCR amplified in parallel with $\beta$ actin cDNA as an internal

2 positive control. For Netrin-1, the sense primer (5'-GAG ACC TTC AAC ACG

3 CCG-3') and antisense primer (5'-GGA AGG TGG ACA GCG AGG-3') (MWG

4 Biotec, Ebersberg, Germany) were derived from Gene Bank sequence of porcine

5 Netrin-1 (accession number DQ368597). Swine actin was amplified using the

6 primers pACTIN sense (5'- GAG ACC TTC AAC ACG CCG-3') and pACTIN

7 antisense (5'-GGA AGG TGG ACA GCG AGG-3') (MWG Biotec, Ebersberg,

8 Germany). An aliquot (5 $\mu \mathrm{l})$ of the cDNA template was amplified by PCR using

$90.5 \mu \mathrm{l}(500 \mathrm{mU})$ Taq polymerase (Fermentas, Hannover, MD, USA) in $50 \mu \mathrm{l} \mathrm{PCR}$

10 buffer containing $10 \mathrm{mM}$ dNTP mix (Fermentas), $25 \mu \mathrm{M}$ for Netrin-1 primers

11 and $5 \mu \mathrm{M}$ for Actin primers. Amplification was carried out using the thermal

12 cycler PTC-100 Peltier (MJ Research, San Francisco, CA, USA). After an initial

13 denaturation step for $5 \mathrm{~min}$ at $95^{\circ} \mathrm{C}$, target cDNA was amplified for 3 cycles

14 with a denaturation step at $95^{\circ} \mathrm{C}$ for $30 \mathrm{sec}$, annealing at $60{ }^{\circ} \mathrm{C}$ for $30 \mathrm{sec}$ (-

$151^{\circ} \mathrm{C}$ in the second and third cycle), elongation at $72{ }^{\circ} \mathrm{C}$ for $30 \mathrm{sec}$, and for 35

16 cycles with a denaturation step at $95^{\circ} \mathrm{C}$ for $30 \mathrm{sec}$, annealing at $57^{\circ} \mathrm{C}$ for 30

$17 \mathrm{sec}$, elongation at $72{ }^{\circ} \mathrm{C}$ for $30 \mathrm{sec}$. Reactions were terminated with a final

18 elongation at $72{ }^{\circ} \mathrm{C}$ for $10 \mathrm{~min}$. The PCR products were separated on $1.5 \%$

19 agarose gel stained with ethidium bromide $(0.5 \mu \mathrm{g} / \mathrm{ml})$ and visualized under UV

20 light. Digital images were captured by Power Shot A610 photo camera (Canon,

21 Tokyo, Japan). Quantification of band intensity was performed with NIH Image

22 software (Scion Corporation, MA, USA, http://rsb.info.nih.gov/nih-image/). 


\section{$1 \quad 2.3$ Netrin-1 effects on swine granulosa cell functions}

2

3 2.3.1 Granulosa cell culture

4 Granulosa cells were aseptically harvested by aspiration of follicles with a 26-

5 gauge needle, released in medium containing heparin (50 IU/ml), centrifuged

6 for pelleting and then treated with $0.9 \%$ prewarmed ammonium chloride at

$737^{\circ} \mathrm{C}$ for $1 \mathrm{~min}$ to remove red blood cells. Cell number and viability were

8 estimated using a haemocytometer under a phase contrast microscope after

9 vital staining with trypan blue $(0.4 \%)$ of an aliquot of the cell suspension. Cells

10 were seeded in DMEM/Ham's F12 supplemented with sodium bicarbonate (2.2

$11 \mathrm{mg} / \mathrm{ml})$, bovine serum albumin (BSA 0.1\%), penicillin $(100 \mathrm{IU} / \mathrm{ml})$, streptomycin

$12(100 \mu \mathrm{g} / \mathrm{ml})$, amphotericin B $(2.5 \mu \mathrm{g} / \mathrm{ml})$, selenium $(5 \mathrm{ng} / \mathrm{ml})$ and transferrin (5

$13 \mu \mathrm{g} / \mathrm{ml}$ ). Once seeded, cells were incubated for $48 \mathrm{~h}$ at $37^{\circ} \mathrm{C}$ under humidified

14 atmosphere $\left(5 \% \mathrm{CO}_{2}\right)$ in the presence or absence of Netrin-1 at the concentration of 5,30 and $100 \mathrm{ng} / \mathrm{ml}$. The protein was produced as reported by Serafini et al., 1994. Briefly, cDNAs encoding chick Netrin-1 tagged with a cmyc epitope at its C-terminus and fused to the constant (Fc) region of the human IgG1, were subcloned into the expression vector pCEP4 (Invitrogen, Carlsbad, California) and used to transfect 293-EBNA cells (Invitrogen, Carlsbad, California). Protein was finally purified from conditioned media by heparin affinity chromatography to $85-90 \%$ homogeneity, as assessed by silver staining (Keini-Masu et al., 1996). 


\section{$1 \quad$ 2.3.2 Granulosa cell viability}

$22 \times 10^{5}$ cells were seeded in 96-well plates in $200 \mu \mathrm{l} \mathrm{CM}$. Cell proliferation was 3 assayed using a bioluminescent assay (ATP-lites; Packard Bioscience,

4 Groningen, Netherlands) which measured intracellular ATP levels. ATP, being 5 present in all metabolically active cells, is a viability marker whose 6 concentration declines very rapidly when the cells undergo necrosis or 7 apoptosis. The ATP lite-M assay system is based on the production of light 8 caused by the reaction of ATP with added luciferase and D-luciferin. The 9 emitted light is proportional to the ATP concentration. Briefly, $50 \mu \mathrm{l}$ of 10 mammalian cell lysis solution were added to $100 \mu \mathrm{l}$ of cell suspension and the

11 plate was shaken for 5 minutes in an orbital shaker at $700 \mathrm{rpm}$ in order to lyse

12 the cells and stabilize ATP. Then $50 \mu$ of substrate solution were added to the

13 wells and the microplate was shaken for 5 minutes in an orbital shaker at 700

$14 \mathrm{rpm}$. The plate was placed in the dark for 10 minutes and the luminescence

15 was measured in a luminometer (Victor, Packard Bioscience, Groningen, 16 Netherlands).

\subsubsection{Granulosa cell steroid production.}

$1910^{4}$ cells/well were seeded in 96-well plates in $200 \mu$ of CM supplemented with

20 androstenedione $(28 \mathrm{ng} / \mathrm{ml})$. Culture media were then collected, frozen and 21 stored at $-20{ }^{\circ} \mathrm{C}$ until progesterone (P4) and estradiol $17 \beta$ (E2) were 22 determined by a validated Radio Immuno Assays (Grasselli et al., 1993). P4 23 assay sensitivity and $\mathrm{ED}_{50}$ were 0.24 and $1 \mathrm{nmol} / \mathrm{l}$, respectively; E2 assay 
1 sensitivity and $\mathrm{ED}_{50}$ were 0.05 and $0.2 \mathrm{nmol} / \mathrm{l}$. The intra- and inter-assay

2 coefficients of variation were less than $12 \%$ for both assays.

3

$4 \quad 2.4$ Netrin-1 effects on swine aortic endothelial cell functions

$6 \quad$ 2.4.1 Aortic endothelial cell culture

7 An immortalized porcine aortic endothelial cell line (AOC) (Carrillo et al. 2002)

8 was generously provided by José Yelamos (Hospital Universitario Virgen de la

9 Arrixaca, El Palmar, 30120 Murcia, Spain). Cells were cultured in M199 medium

10 supplemented with sodium bicarbonate $(2.2 \mathrm{mg} / \mathrm{ml})$, FCS $20 \%$, penicillin (100

$11 \mathrm{IU} / \mathrm{ml})$, streptomycin $(100 \mu \mathrm{g} / \mathrm{ml})$, amphotericin $B(2.5 \mu \mathrm{g} / \mathrm{ml})$. In all

12 experiments, AOC at $19^{\text {th }}$ passage were used.

\section{$14 \quad$ 2.4.2 Angiogenesis bioassay}

15 The microcarrier-based fibrin gel angiogenesis assay was performed as

16 described by Basini et al. (2008) with some modifications. Briefly, $12.5 \mathrm{mg}$

17 gelatin-coated cytodex-3 microcarriers in $1 \mathrm{ml}$ PBS were incubated for $3 \mathrm{~h}$ to 18 hydrate. After two washings in PBS and one in CM, the microcarriers were put

19 in flasks containg $5 \mathrm{ml} \mathrm{CM}$; AOC $\left(5 \times 10^{5}\right)$ were added and cultured for $24 \mathrm{~h}$ in

20 order to let the endothelial cells coat the microcarriers. For the fibrin gel 21 preparation, $40 \mu \mathrm{l}$ microcarriers covered by AOC were pipetted into 6 well 22 plates containing a solution of fibrinogen (1mg/ml PBS, $\mathrm{pH} 7.6)$, added with

$231250 \mathrm{IU}$ thrombine $(250 \mu \mathrm{l})$. Fibrin gels were allowed to polymerize for $30 \mathrm{~min}$ 
1 at $37^{\circ} \mathrm{C}$, and then were equilibrated for $60 \mathrm{~min}$ with $2 \mathrm{ml} \mathrm{M199.} \mathrm{After} \mathrm{a} \mathrm{change}$

2 of the medium, $\mathrm{AOC}$ were incubated in the presence or absence of 5,30 or 100

$3 \mathrm{ng} / \mathrm{ml}$ of Netrin-1. Plates were incubated at $37^{\circ} \mathrm{C}$ under humidified atmosphere

$4 \quad\left(5 \% \mathrm{CO}_{2}\right) . \mathrm{AOC}$ were cultured for $96 \mathrm{~h}$, renewing totally the treatment after $48 \mathrm{~h}$

5 as described above.

6

7 2.4.3 Quantification of AOC growth on fibrin gel matrix

8 Endothelial cell proliferation in the fibrin gel matrix was evaluated by means of

9 the public domain NIH Program Scion Image Beta 4.02. Ten pictures were

10 taken for each gel at 48 and $96 \mathrm{~h}$; images were converted into gray scale,

11 resized to 50\% (Paintbrush Software, MS Office) and saved as Bitmap 24bit

12 format compatible with Scion. The modified images were then imported into the

13 program and measurements were made drawing the perimeter of the area

14 occupied by AOC expressed as number of pixel. In order to validate the

15 measurement of the area covered by $\mathrm{AOC}$ in fibrin gels as a reliable method to

16 evaluate cell proliferation, fibrin gels were stained by the nuclear dye bis-

17 benzimide (Hoechst 33258, $20 \mu \mathrm{g} / \mathrm{ml}$ in PBS for $60 \mathrm{~min}$ ) and examined by the

18 fluorescence microscope. This procedure was performed 20 times; for each

19 experiment the number of nuclei was counted under fluorescence and pictures

20 of the aera covered by $\mathrm{AOC}$ were taken in order to measure the surface

21 covered in the fibrin gel. A strong correlation was observed between the area

22 covered by AOC and the number of nuclei found in the same area $(r=0.96)$. 


\section{$1 \quad$ 2.4.5 Aortic endothelial cell VEGF production}

$22 \times 10^{5}$ cells were seeded in 96-well plates in $200 \mu \mathrm{l}$ M199, in the presence or

3 absence of 5,30 or $100 \mathrm{ng} / \mathrm{ml}$ of Netrin-1 and incubated for $48 \mathrm{~h}$. VEGF content

4 in culture media was quantified by an ELISA (Quantikine, R\&D System,

5 Minneapolis, MI, USA); this assay, developed for human VEGF detection, has

6 been validated for pig VEGF (Barboni et al. 2000). The assay sensitivity was

$7 \quad 8.74 \mathrm{pg} / \mathrm{ml}$, the inter- and intra-assay CVs were always less than $7 \%$. Victor

8 Reader set to read at a wavelength of $450 \mathrm{~nm}$ emission was used to quantify

9 the reaction product.

\section{2.4.6 Aortic endothelial cell NO production}

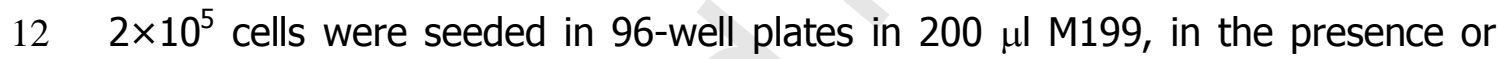

13 absence of 5,30 or $100 \mathrm{ng} / \mathrm{ml}$ of Netrin-1 and incubated for $48 \mathrm{~h}$. Nitric oxide

14 (NO) was assessed by measuring nitrite levels in culture media by microplate 15 method based on the formation of a chromophore after reaction with Greiss

16 reagent, which was prepared fresh daily by mixing equal volumes of stock $A$

17 (1\% sulfanilamide, $5 \%$ phosphoric acid) and stock B $(0.1 \% \mathrm{~N}$-[naphtyl]

18 ethylenediamine dhydrochloride). After incubation with Greiss reagent the

19 absorbance was determined with the Victor Reader using a $540 \mathrm{~nm}$ against 620

$20 \mathrm{~nm}$ filter. A calibration curve ranging from 25 to $0.39 \mu \mathrm{M}$ was prepared by

21 diluting sodium nitrite in culture medium.

\subsection{Statistical analysis.}


1 Data are presented as means \pm SEM. Statistical analysis was performed by

2 means of ANOVA using Statgraphics package (STSC Inc., Rockville, MD, USA).

3 When significant differences were found, means were compared by Scheffè's F

4 test. $P$ values $<0.05$ were considered to be statistically significant.

\section{3. Results}

$7 \quad 3.1$ Netrin-1 in swine ovarian follicle

9 3.1.1 Immunohistochemistry

10 Immunostaining of Netrin-1 in swine ovarian follicle wall was undetectable. On

11 the contrary, immunoreaction was localized in the ovarian vessels (Figure $1 \mathrm{~b}$ ).

\subsubsection{Follicular fluid Western Blotting}

14 The immunoblotting showed the presence of Netrin-1 in swine follicular fluid

15 (Figure 2). The band corresponding to Netrin-1, in fact, was resolved at the 16 expected molecular weight of about $70 \mathrm{kDa}$ both in follicular fluid and in a 17 positive control consisting of a soluble protein extract from porcine spinal 18 marrow.

\subsubsection{Netrin-1 gene expression}

21 Netrin-1 expression was evidenced both in granulosa and theca layer from 22 swine follicles (Figure 3). 


\section{$1 \quad 3.2$ Netrin-1 effects on swine granulosa cell functions}

\section{3.2.1 Granulosa cell proliferation}

4 Granulosa cell viability, evaluated as ATP content, was slightly but significantly

$5 \quad(p<0.05)$ inhibited by the treatment with 30 and $100 \mathrm{ng} / \mathrm{ml}$ of Netrin-1 for $48 \mathrm{~h}$.

6 The lowest concentration of Netrin-1 tested, $5 \mathrm{ng} / \mathrm{ml}$, was ineffective (Figure 4).

$8 \quad 3.2 .2$ Granulosa cell steroid production.

9 Granulosa cell steroid production, evaluated by RIA assays, was affected by

10 Netrin-1 treatment for 48 h. E2 production was significantly inhibited $(p<0.01)$

11 by 30 and $100 \mathrm{ng} / \mathrm{ml}$ of Netrin-1 (Figure 5); the same concentrations, on the 12 contrary, stimulated $(p<0.001)$ P4 production (Figure 6). The lowest 13 concentration tested, $5 \mathrm{ng} / \mathrm{ml}$, was ineffective on both steroid secretions 14 (Figure 5 and 6).

\subsection{Netrin-1 effects on swine aortic endothelial cell functions}

\subsubsection{Angiogenesis bioassay}

19 Netrin-1 significantly inhibited $(p<0.05)$ new vessel growth both after 48 and 96

$20 \mathrm{~h}$ of incubation. All the concentrations tested $(5,30$ and $100 \mathrm{ng} / \mathrm{ml})$ exerted the same effect. (Figure 7 and 8).

\subsubsection{Aortic endothelial cell VEGF production}


1 VEGF secretion by $A O C$ was significantly inhibited $(p<0.01)$ by the $48 \mathrm{~h}$

2 treatment with all the examined concentrations of Netrin-1 $(5,30$ and 100

$3 \mathrm{ng} / \mathrm{ml}$ ) (Figure 9).

5 3.3.3 Aortic endothelial cell NO production

6 All Netrin-1 concentrations (5, 30 and $100 \mathrm{ng} / \mathrm{ml}$ ) significantly stimulated

$7 \quad(p<0.01)$ NO generation after $48 \mathrm{~h}$ of incubation (Figure 10$)$.

\section{4. Discussion}

10 Ovarian physiology is connoted by follicular growth, a fundamental event which

11 is strictly dependent on cell proliferation, steroid production and new vessel

12 growth. The molecular machinery which regulates ovarian angiogenesis, though

13 extensively studied, is far to be completely clarified. In a recent review, Larrivée

14 et al. (2009) observe that anatomical and structural similarities between blood

15 vessels and nerves have been highlighted by several studies. Among the

16 molecules with attractive and repulsive properties which have been found to

17 modulate the proper guidance of both nerves and blood vessels, netrin-1

18 displays both pro- and antiangiogenic effects (Park et al., 2004; Castets et al

19 2009). Interestingly, netrin-1 has been found to be expressed in swine

20 granulosa cells from 3-5 mm ovarian follicles, thus suggesting its potential

21 function in follicular function regulation(Maeda et al., 2008).

22 In the present study netrin-1 was evidenced in ovarian vessels but was

23 undetectable in follicular wall. In addition, we document its expression both in 
1 granulosa and the theca layer from swine ovarian follicles $>5 \mathrm{~mm}$ as well as in

2 swine follicular fluid. These data lead us to hypothesize that netrin-1 could play

3 a regulatory role in the function of the ovarian follicle, a structure which

4 represents a typical example of events of proliferation and differentiation.

5 Similarly, Strizzi et al. (2008) demonstrated that mammary gland, a structure

6 subjected to different stages of development and differentiation, expresses

7 netrin-1, which appears to be involved in the fine-tuning of these complex

8 events. In particular, our data show that the protein inhibits granulosa cell

9 viability and E2 synthesis, while it increases P4 production, thus suggesting its

10 involvement in the induction of granulosa cell terminal differentiation. The

11 relationship between growth and differentiation has been a matter of great

12 interest in cellular biology. In granulosa cells, the differentiative function and

13 growth-related process appear inversely controlled (Basini et al., 1998): netrin-

141 could play a pivotal role in the paracrine/autocrine regulation of these events.

15 Since follicular growth is strictly dependent on adequate vascular development,

16 this structure has been suggested as an invaluable physiological model of

17 angiogenesis, a process which represents an important aspect of growth and

18 metastasis of solid tumors (Grimm et al 2009). The similarities between nerve

19 and blood vessel guidance have attracted considerable interest towards the

20 study of a potential involvement of neurotropic factors in angiogenesis control

21 (Strizzi et al., 2009).

22 Among these, netrin-1 deserves particular attention even if its exact role in 23 angiogenesis is still doubtful since numerous studies report both pro- or 
1 antiangiogenic activities (Bradford et al., 2009). The results obtained in the

2 fibrin bioassay demonstrate an inhibition of angiogenesis by netrin-1. This is in

3 agreement with Lu et al. (2004), but contrary to Park et al. (2004) and Wilson

4 et al. (2006) who suggested that netrin-1 stimulates new vessel growth.

5 Therefore, it appears that netrin-1 function, as already demonstrated in the

6 nervous system (Masuda et al., 2009), could be dependent on receptor type as

7 well as on the intracellular signal transduction pathways activated by each

8 receptor. Further studies will be needed in order to investigate this fundamental

9 topic in our experimental model. Our data also suggest, for the first time, that

10 this effect most likely appears to be mediated by an inhibition of VEGF

11 production by endothelial cells. Moreover, our data are in agreement with

12 Nguyen et al. (2006) demonstrate that netrin-1 appears to increase NO output

13 by endothelial cells. It should be noted that the role of NO in angiogenesis

14 regulation is far from being clarified. Several studies suggest a stimulatory

15 effect (Kimura et al., 2000; Dulak et al., 2000; Sandau et al., 2000) while

16 others point out inhibitory effects (Powell et al., 2000; Santini et al., 2009). The

17 reasons for these discrepancies are still unknown, even if NO levels could play

18 an important role (Kimura et al. 2003).

19 Taken together our data demonstrate that netrin-1 is physiologically present in

20 swine ovary and it is likely involved in modulating follicular function. In

21 particular, data obtained in granulosa cells let us to hypothesize that netrin-1

22 could be important for granulosa cell terminal differentiation; moreover, the

23 observations in endothelial cells seem to suggest its involvement in the control 
1 of new vessel growth. Further studies are strongly advisable to address netrin-1

2 function since the molecular machinery responsible for angiogenesis inhibition is

3 far to be clarified.

\section{Acknowledgements}

6 We would like to thank Professor Hinck, Department of Molecular, Cell and

7 Developmental Biology, University of California, Santa Cruz, California and

8 Professor Yelamos (Department of Biochemistry, Molecular Biology and

9 Immunology, Facultad de Medicina, Universidad de Murcia, Spain) for supplying

10 AOC. This research was supported by a FIL and MIUR PRIN grants.

\section{References}

14 Barboni, B., Turriani, M., Galeati, G., Spinaci, M., Bacci, M.L., Forni, M., Mattioli,

15 M., 2000. Vascular endothelial growth factor production in growing pig antral 16 follicles. Biol. Reprod. 63, 858-864.

17 Basini, G., Baratta, M., Bussolati, S., Tamanini, C., 1998. Interleukin-1 beta 18 fragment (163-171) modulates bovine granulosa cell proliferation in vitro:

19 dependence on size of follicle. J. Reprod. Immunol. 37, 139-153.

20 Basini, G., Bussolati, S., Santini, S.E., Bianchi, F., Careri, M., Mangia, A., Musci,

21 M., Grasselli, F., 2008a. Hydroxyestrogens inhibit angiogenesis in swine ovarian

22 follicles. J. Endocrinol. 199, 127-135. 
1 Basini, G., Bussolati S., Santini S.E., Grasselli F., 2008b. Reactive oxygen

2 species and anti-oxidant defences in swine follicular fluids. Reprod. Fertil. Dev. $320,269-274$.

4 Basini, G., Baioni, L., Bussolati, S., Grolli, S., Kramer, LH, Wagner, G.F.,

5 Grasselli F., 2010. Expression and localization of stanniocalcin 1 in swine ovary.

6 Gen. Comp. Endocrinol. 166, 404-408.

7 Bouvrée, K., Larrivée, B., Lv, X., Yuan, L., DeLafarge, B., Freitas, C., Mathivet,

8 T., Bréant, C., Tessier-Lavigne, M., Bikfalvi, A., Eichmann, A., Pardanaud, L.,

9 2008. Netrin-1 inhibits sprouting angiogenesis in developing avian embryos.

10 Dev Biol. 318 172-183.

11 Bradford, D., Cole, S.J., Cooper, H.M., 2009. Netrin-1: diversity in development.

12 Int. J. Biochem. Cell. Biol. 413 487-493.

13 Carrello, S., Chamorro, M., Rodriguez-Gago, B., Alvarez, M.J., Molina, J.I., 14 Rodriguez-Barbosa, A., Sanchez, P., Ramirez, A., Munoz, J., Dominguez, J., 15 Parrilla, P., Yelamos, J. 2002. Isolation and characterization of immortalized 16 porcine aortic endothelial cell lines. Vet. Immunol. Immunopathol. 89, 91-98.

17 Castets, M., Coissieux, M.M., Delloye-Bourgeois, C., Bernard, L., Delcros, J.G., 18 Bernet, A., Laudet, V., Mehlen, P., 2009. Inhibition of endothelial cell apoptosis 19 by netrin-1 during angiogenesis. Dev. Cell. 16 614-620.

20 Cirulli, V., Yebra, M., 2007. Netrins: beyond the brain. Nat. Rev. Mol. Cell. Biol. $218,296-306$.

22 Dulak, J., Józkowicz, A, Dembinska-Kiec, A., Guevara, I., Zdzienicka, A., 23 Zmudzinska-Grochot, D., Florek, I., Wójtowicz, A., Szuba, A., Cooke, J.P., 2000. 
1 Nitric oxide induces the synthesis of vascular endothelial growth factor by rat

2 vascular smooth muscle cells. Arterioscler. Thromb. Vasc. Biol. 20, 659-666.

3 Grasselli, F., Baratta, M., Tamanini, C., 1993. Effects of a GnRH analogue

4 (buserelin) infused via osmotic minipumps on pituitary and ovarian activity of

5 prepuberal heifers. Anim. Reprod. Sci. 32, 153-161.

6 Keino-Masu, K., Masu, M., Hinck, L., Leonardo, E.D., Chan, S.S., Culotti, J.G.,

7 Tessier-Lavigne, M., 1996. Deleted in Colorectal Cancer (DCC) encodes a netrin

8 receptor. Cell. $87,175-185$.

9 Kimura, H., Esumi, H., 2003. Reciprocal regulation between nitric oxide and

10 vascular endothelial growth factor in angiogenesis. Acta Biochim. Pol. 50, 49-

1159.

12 Laemmli, U.K. 1970. Cleavage of structural proteins during the assembly of the

13 head of bacteriophage T4. Nature $227,680-685$.

14 Larrivée, B., Freitas, C., Trombe, M., Lv, X., Delafarge, B., Yuan, L., Bouvrée,

15 K., Bréant, C., Del Toro, R., Bréchot, N., Germain, S., Bono, F., Dol, F., Claes,

16 F., Fischer, C., Autiero, M., Thomas, J.L., Carmeliet, P., Tessier-Lavigne, M.,

17 Eichmann, A. 2007. Activation of the UNC5B receptor by Netrin-1 inhibits

18 sprouting angiogenesis. Genes Dev. 21, 2433-2447.

19 Larrivée, B., Freitas, C., Suchting, S., Brunet, I., Eichmann, A., 2009. Guidance

20 of vascular development: lessons from the nervous system. Circ. Res. 104, 428-

21441.

22 Lu, X., Le Noble, F., Yuan, L., Jiang, Q., De Lafarge, B., Sugiyama, D., Bréant,

23 C., Claes, F., De Smet, F., Thomas, J.L., Autiero, M., Carmeliet, P., Tessier- 
1 Lavigne, M., Eichmann, A., 2004. The netrin receptor UNC5B mediates guidance

2 events controlling morphogenesis of the vascular system. Nature 432, 179-186.

3 Maeda, A., Matsuda, F., Goto, Y., Cheng, Y., Gonda, H., Inoue, N., Nakagawa,

4 S., Manabe, N., 2008. Molecular cloning of a porcine (Sus scrofa) apoptosis

5 inhibitory ligand, netrin-1, and its receptor, p53RDL1. J. Reprod. Dev. 54, 275-

6280.

7 Masuda, T., Yaginuma, H., Sakuma, C., Ono, K., 2009. Netrin-1 signaling for

8 sensory axons: Involvement in sensory axonal development and regeneration.

9 Cell. Adh. Migr. 3, 171-173.

10 Nguyen, A., Cai, H., 2006. Netrin-1 induces angiogenesis via a DCC-dependent

11 ERK1/2-eNOS feed-forward mechanism. Proc. Natl. Acad. Sci. U S A. 103, 6530-

126535.

13 Park, K.W., Crouse, D., Lee, M., Karnik, S.K., Sorensen, L.K., Murphy, K.J., Kuo,

14 C.J., Li, D.Y., 2004. The axonal attractant Netrin-1 is an angiogenic factor. Proc.

15 Natl. Acad. Sci. U S A. 101, 16210-16215.

16 Powell, J.A., Mohamed, S.N., Kerr, J.S., Mousa, S.A., 2000. Antiangiogenesis

17 efficacy of nitric oxide donors. J. Cell. Biochem. 80, 104-114.

18 Sandau, K.B., Fandrey, J., Brüne, B., 2001. Accumulation of HIF-1alpha under

19 the influence of nitric oxide. Blood 97, 1009-1015.

20 Santini, S.E., Basini, G., Bussolati, S., Grasselli, F., 2009. The phytoestrogen

21 quercetin impairs steroidogenesis and angiogenesis in swine granulosa cells in

22 vitro. J. Biomed. Biotechnol. 2009-419891 
1 Serafini, T., Kennedy, T.E., Galko, M.J., Mirzayan, C., Jessell, T.M., Tessier-

2 Lavigne, M., 1994. The netrins define a family of axon outgrowth-promoting

3 proteins homologous to C. elegans UNC-6. Cell 78, 409-424.

4 Strizzi, L., Mancino, M., Bianco, C., Raafat, A., Gonzales, M., Booth, B.W.,

5 Watanabe, K., Nagaoka, T., Mack, D.L., Howard, B., Callahan, R., Smith, G.H.,

6 Salomon, D.S. 2008. Netrin-1 can affect morphogenesis and differentiation of

7 the mouse mammary gland. J. Cell. Physiol. 216, 824-834.

8 Towbin, H., Staehelin, T., Gordon, J., 1979. Electrophoretic transfer of proteins

9 from polyacrylamide gels to nitrocellulose sheets: procedure and some 10 applications.Proc Natl Acad Sci U S A. 76, 4350-4354.

11 


\section{Figure captions}

Figure 1. Immunohistochemical localization of Netrin 1 in swine ovary. A: antral follicles. B: vessel. C: follicle walls. D: corpus luteum. A positive signal has been detected only in vessels ( $B$, see arrows).

Figure 2. Netrin 1 protein in swine follicular fluid and spinal marrow revealed by immunoblotting. Protein bands on SDS-PAGE gel were stained with Comassie blue.

Figure 3. Netrin-1 expression in swine granulosa and theca cells collected from swine follicles. The representative ethidium bromide-stained gel shows ACT and STC 1 amplicons from at least three follicles.

Figure 4. Effect of the $48 \mathrm{~h}$ treatment with or without (C) Netrin-1 at the concentrations of 5,30 or $100 \mathrm{ng} / \mathrm{ml}$ on granulosa cell viability evaluated as ATP content. Data, expressed as $\%$ vs respective $C$, represent the mean \pm SEM of six replicates/treatment repeated in four different experiments. Different letters indicate a significant difference $(p<0.05)$.

Figure 5. Effect of the $48 \mathrm{~h}$ treatment with or without (C) Netrin-1 at the concentrations of 5,30 or $100 \mathrm{ng} / \mathrm{ml}$ on E2 production in swine granulosa cell culture evaluated by RIA. Data, expressed as $\mathrm{ng} / \mathrm{ml}$, represent the mean $\pm \mathrm{SEM}$ 
1 of six replicates/treatment repeated in four different experiments. The absence

2 of common letters indicate a significant difference $(p<0.01)$.

3

4 Figure 6. Effect of the $48 \mathrm{~h}$ treatment with or without (C) Netrin-1 at the

5 concentrations of 5,30 or $100 \mathrm{ng} / \mathrm{ml}$ on $\mathrm{P} 4$ production in swine granulosa cell

6 culture evaluated by RIA. Data, expressed as $\mathrm{ng} / \mathrm{ml}$, represent the mean \pm SEM

7 of six replicates/treatment repeated in four different experiments. Different

8 letters indicate a significant difference $(p<0.001)$.

9

10 Figure 7. Effect of the $48 \mathrm{~h}$ treatment with or without (C) Netrin-1 at the

11 concentrations of 5,30 or $100 \mathrm{ng} / \mathrm{ml}$ on $\mathrm{AOC}$ growth in fibrin gel. Panel A:

12 phase contrast micrographs showing $\mathrm{AOC}$ growth at $48 \mathrm{~h}$ in fibrin gel matrix.

13 Panel B: area covered by AOC. Data, expressed as \% vs respective C, represent

14 the mean \pm SEM of six replicates/treatment repeated in four different

15 experiments. Different letters indicate a significant difference $(p<0.05)$.

17 Figure 8. Effect of the $96 \mathrm{~h}$ treatment with or without (C) Netrin-1 at the 18 concentrations of 5,30 or $100 \mathrm{ng} / \mathrm{ml}$ on $\mathrm{AOC}$ growth in fibrin gel. Panel A:

19 phase contrast micrographs showing AOC growth at $96 \mathrm{~h}$ in fibrin gel matrix.

20 Panel B: area covered by AOC. Data, expressed as \% vs respective C, represent

21 the mean \pm SEM of six replicates/treatment repeated in four different

22 experiments. Different letters indicate a significant difference $(p<0.05)$. 
1 Figure 9. Effect of the $48 \mathrm{~h}$ treatment with or without (C) Netrin-1 at the

2 concentrations of 5,30 or $100 \mathrm{ng} / \mathrm{ml}$ on VEGF production, evaluated by ELISA,

3 by $A O C$ culture. Data, expressed as $\mathrm{pg} / \mathrm{ml}$, represent the mean $\pm \mathrm{SEM}$ of six

4 replicates/treatment repeated in four different experiments. Different letters

5 indicate a significant difference $(p<0.01)$.

6

7 Figure 10 . Effect of the $48 \mathrm{~h}$ treatment with or without (C) Netrin-1 at the

8 concentrations of 5,30 or $100 \mathrm{ng} / \mathrm{ml}$ on NO production, evaluated by Greiss

9 method, by AOC culture. Data, expressed as $\mu M$, represent the mean \pm SEM of

10 six replicates/treatment repeated in four different experiments. The absence of

11 common letters indicate a significant difference $(p<0.01)$. 

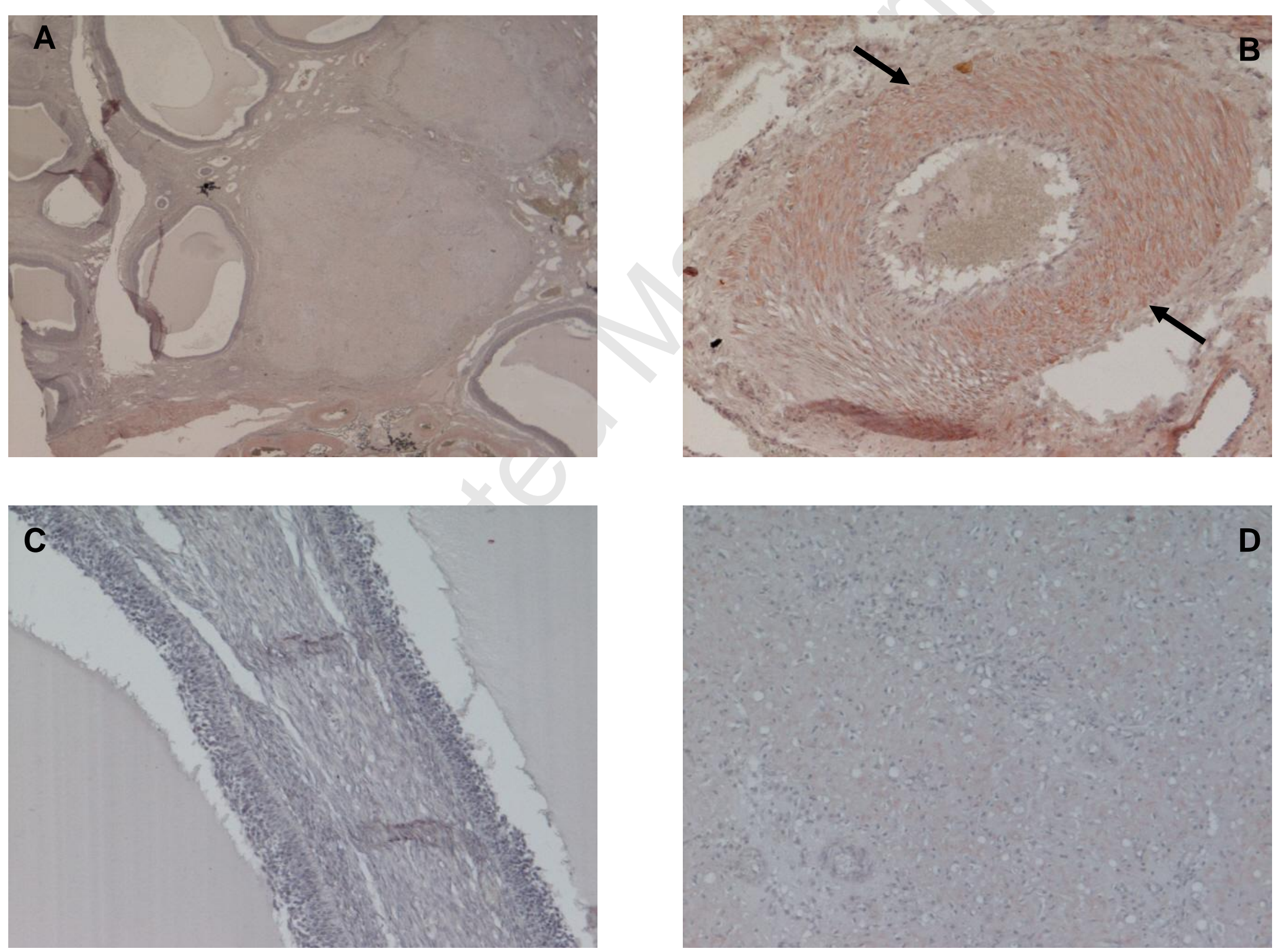


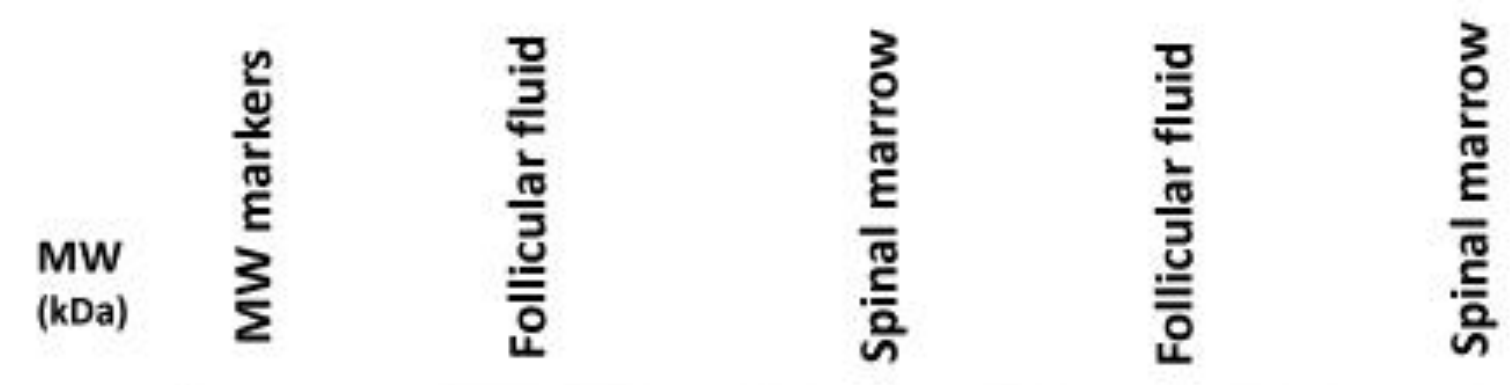

116 -

66 -

45 -

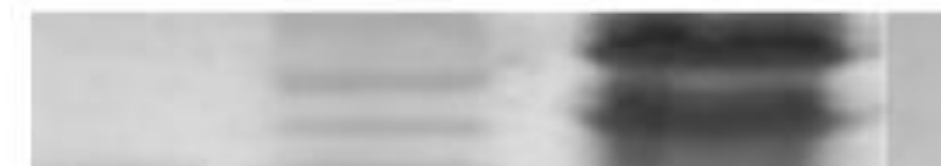

35 -

SDS-PAGE

Immunoblotting 
Figure 3

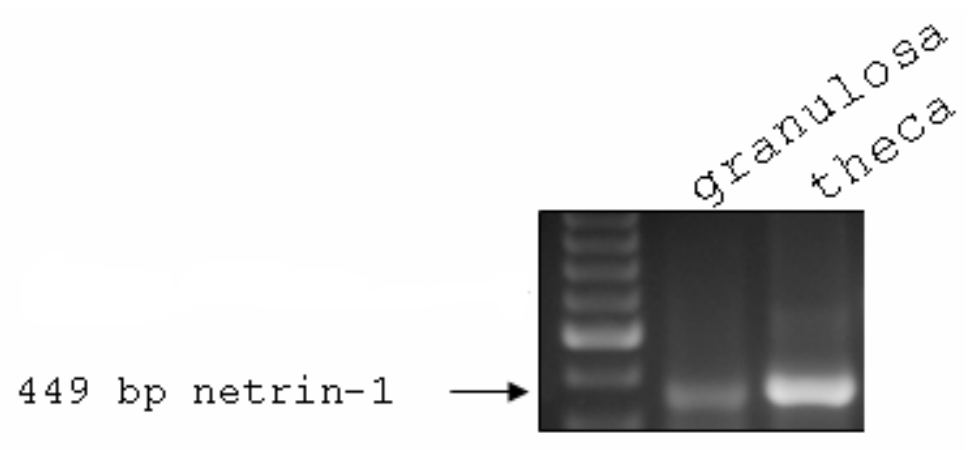


Figure 4

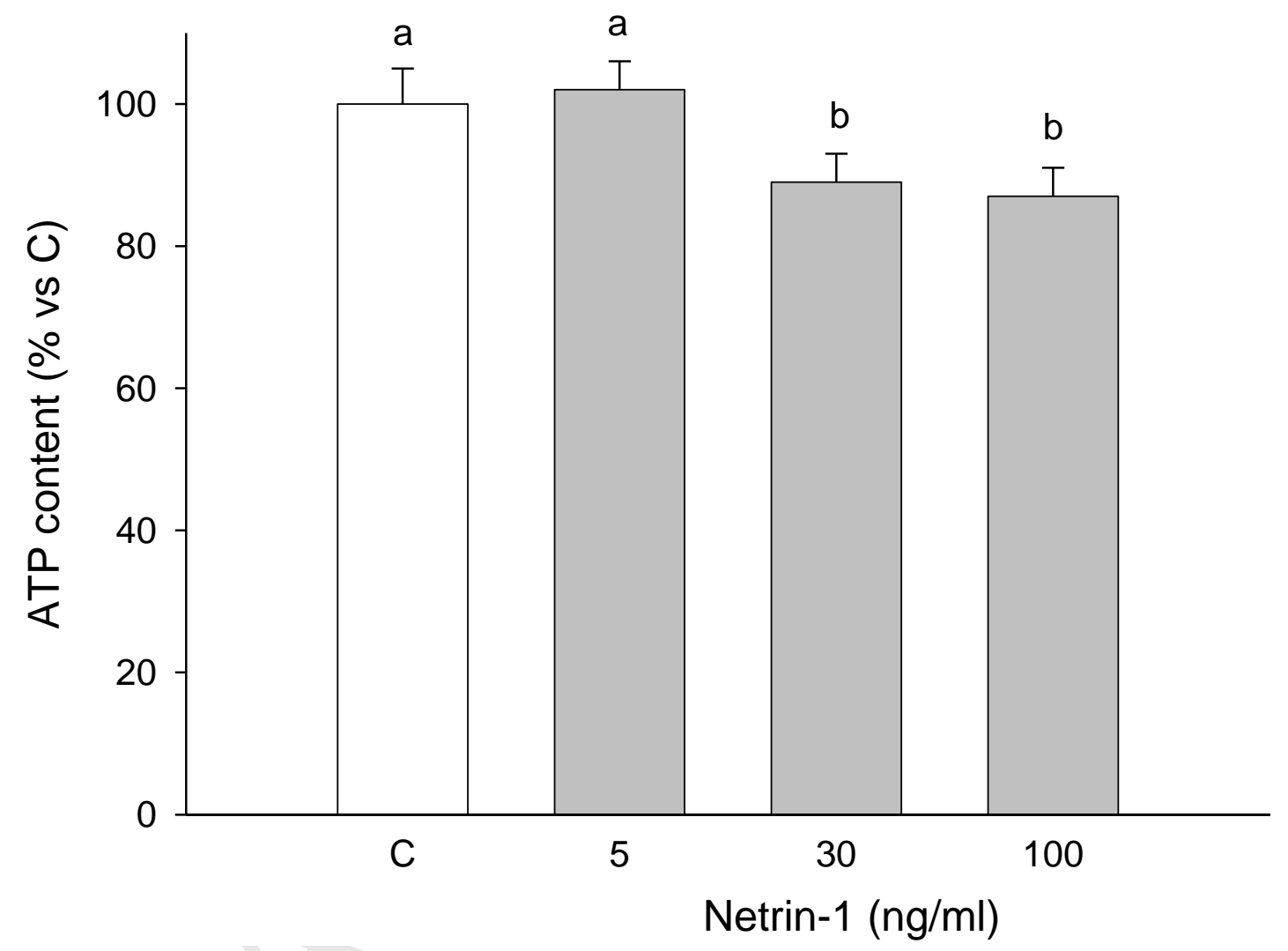


Figure 5

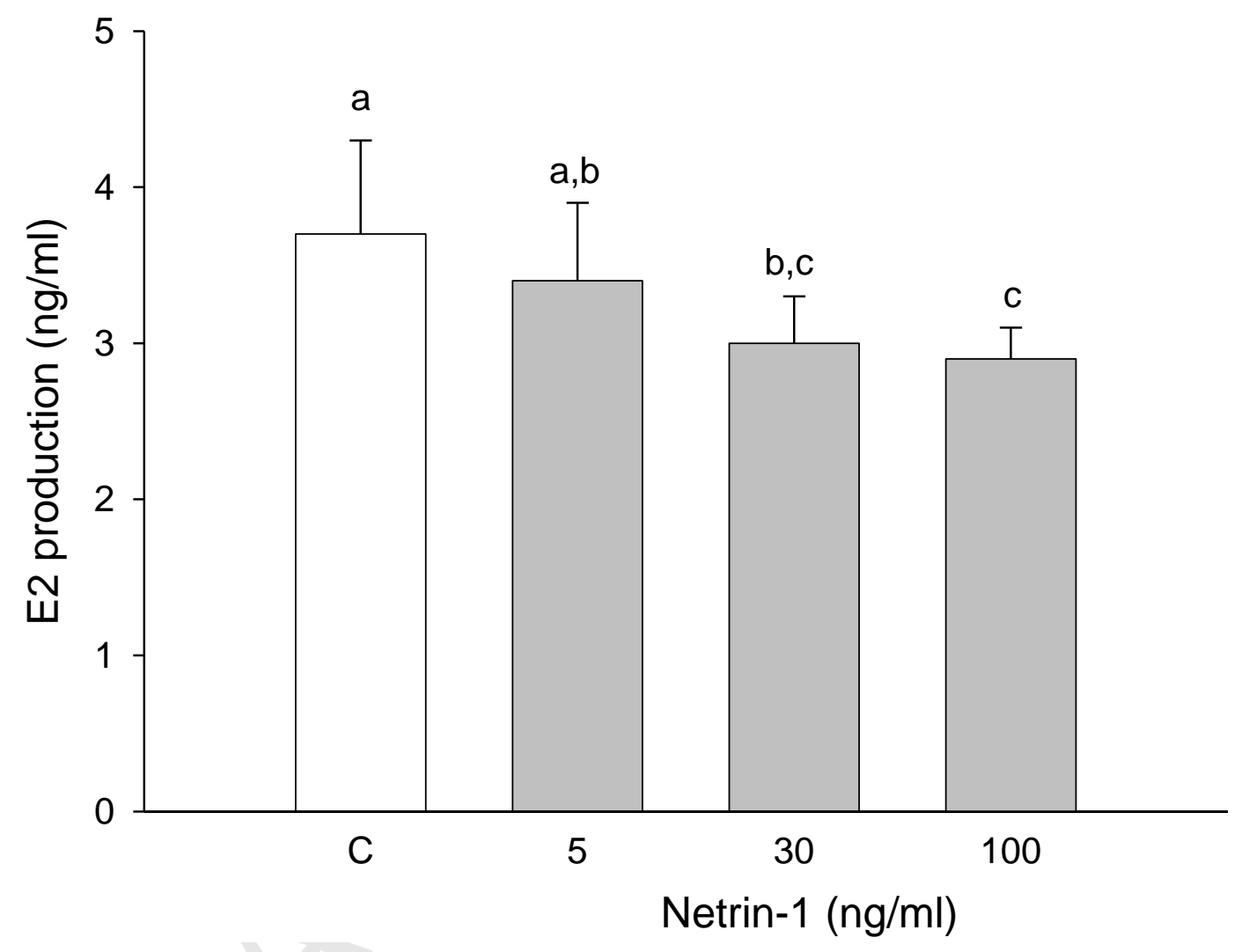


Figure 6

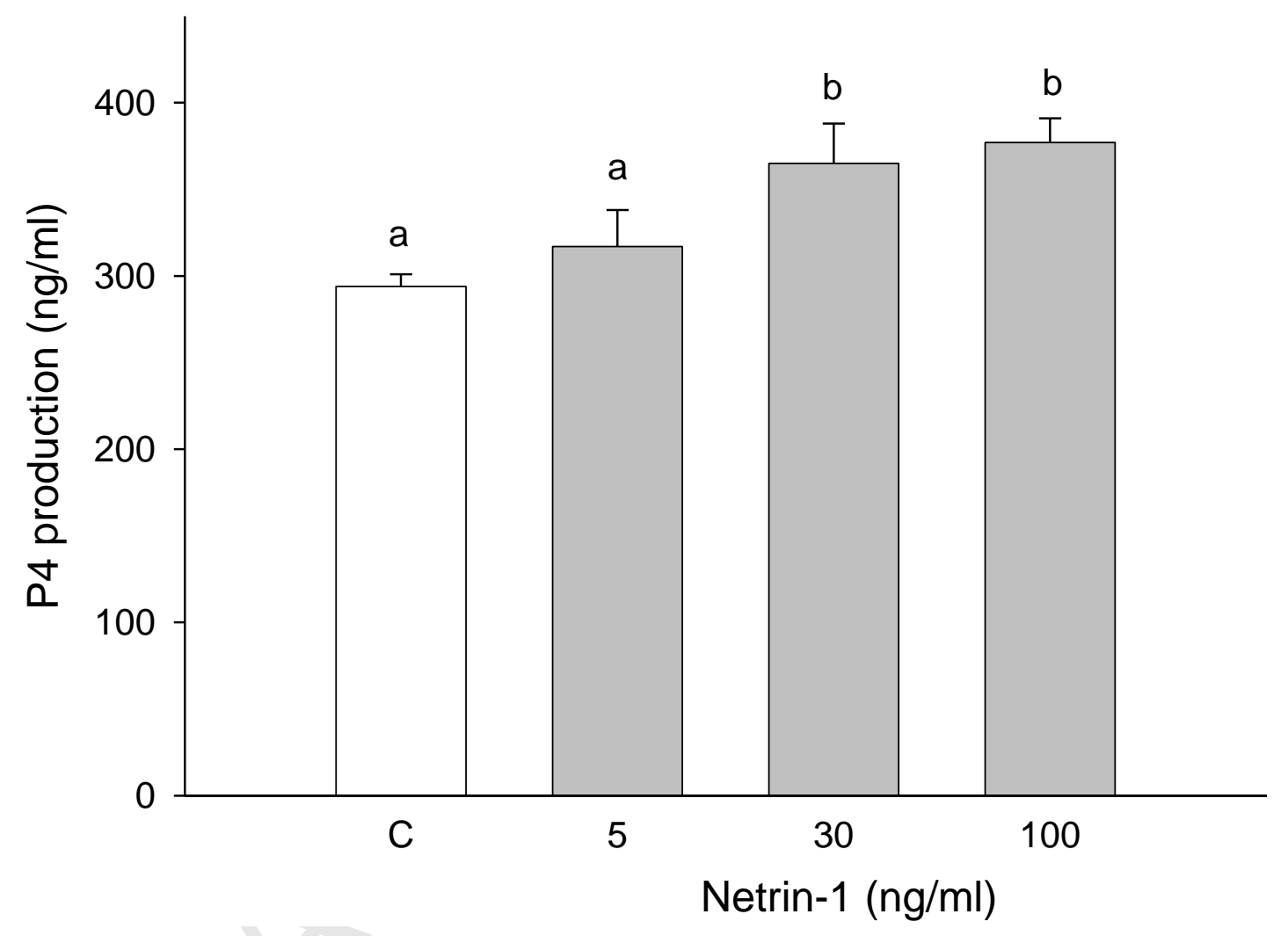


Figure 7
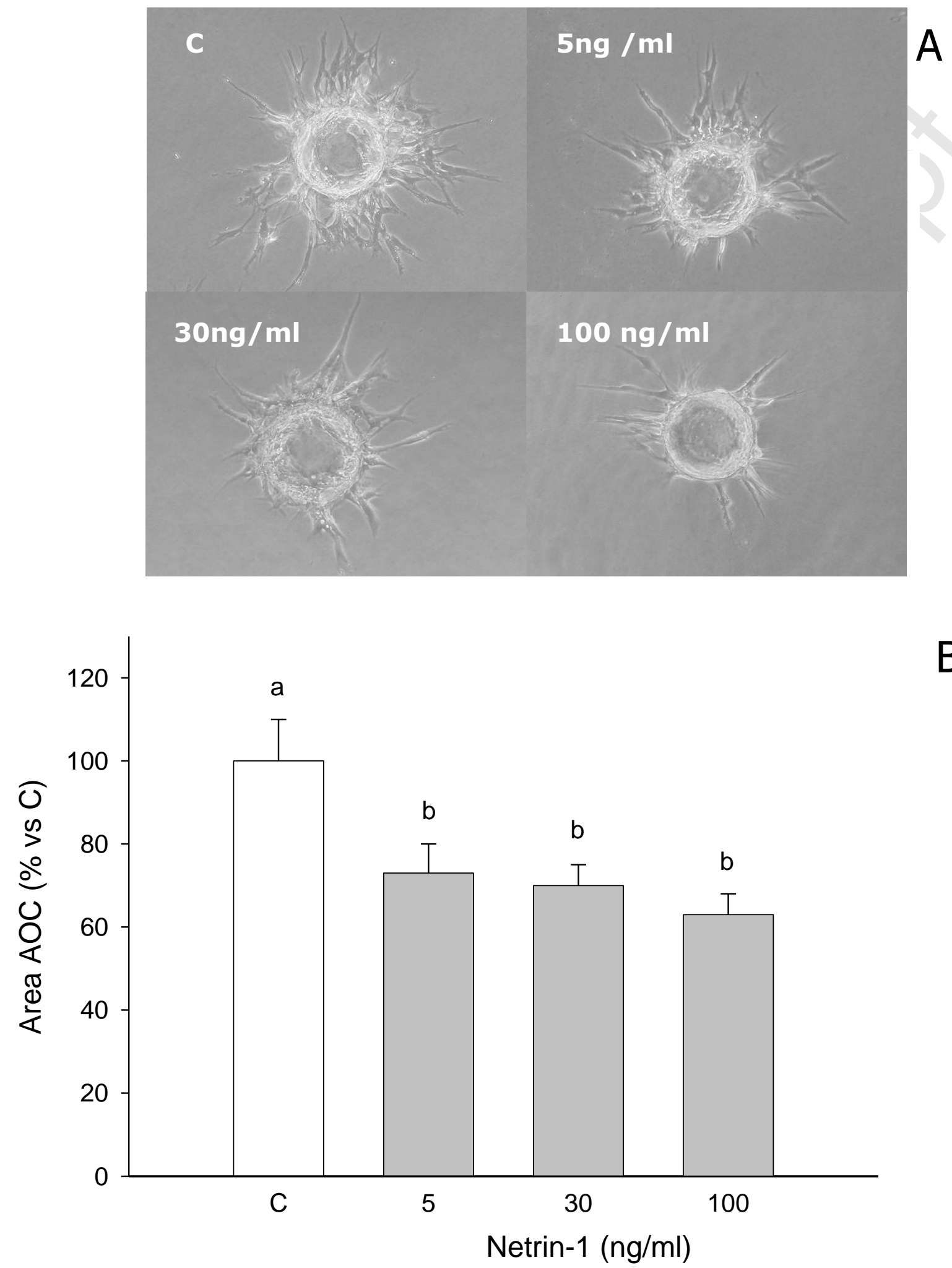

B 
Figure 8
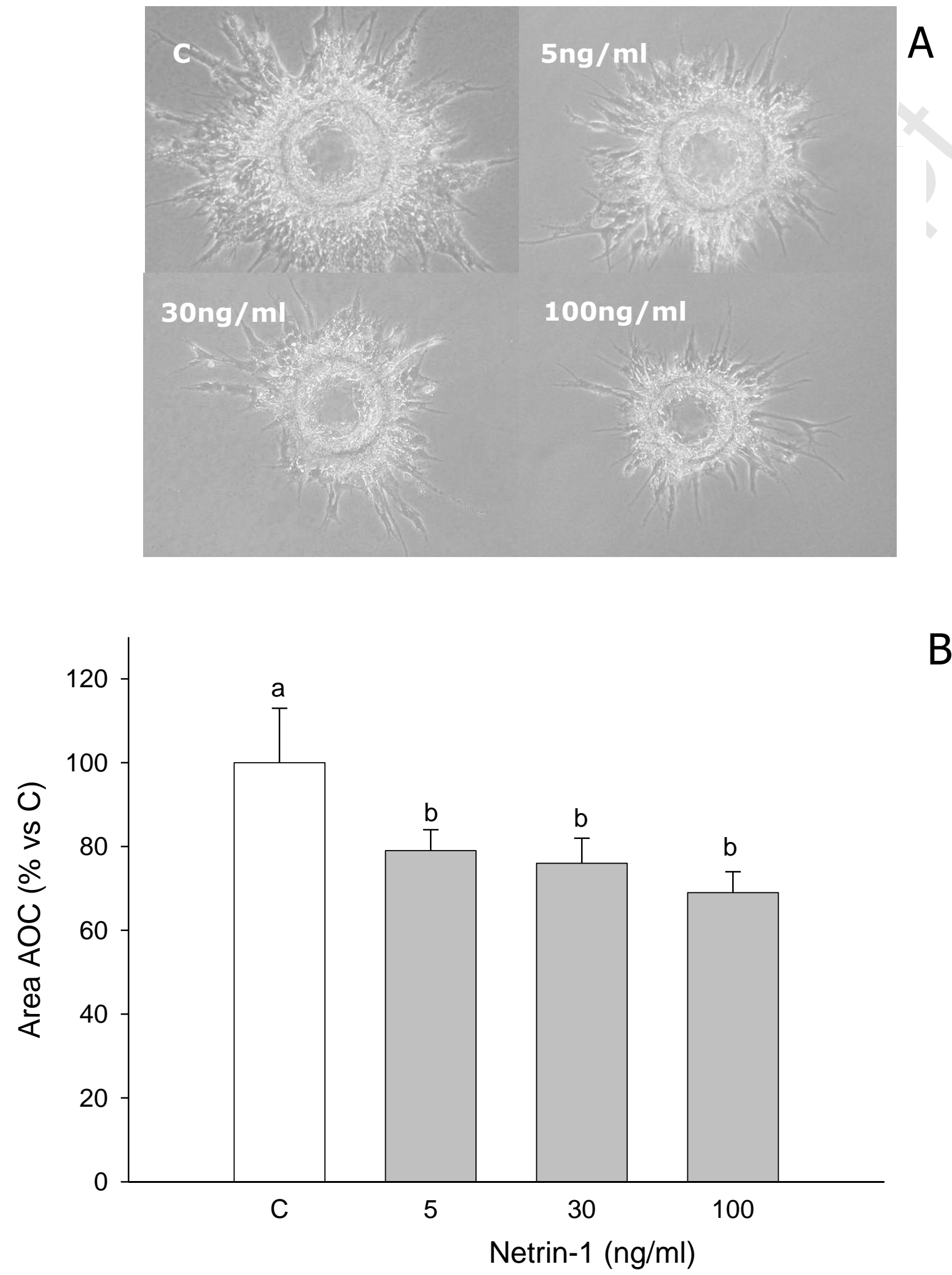

B 
Figure 9

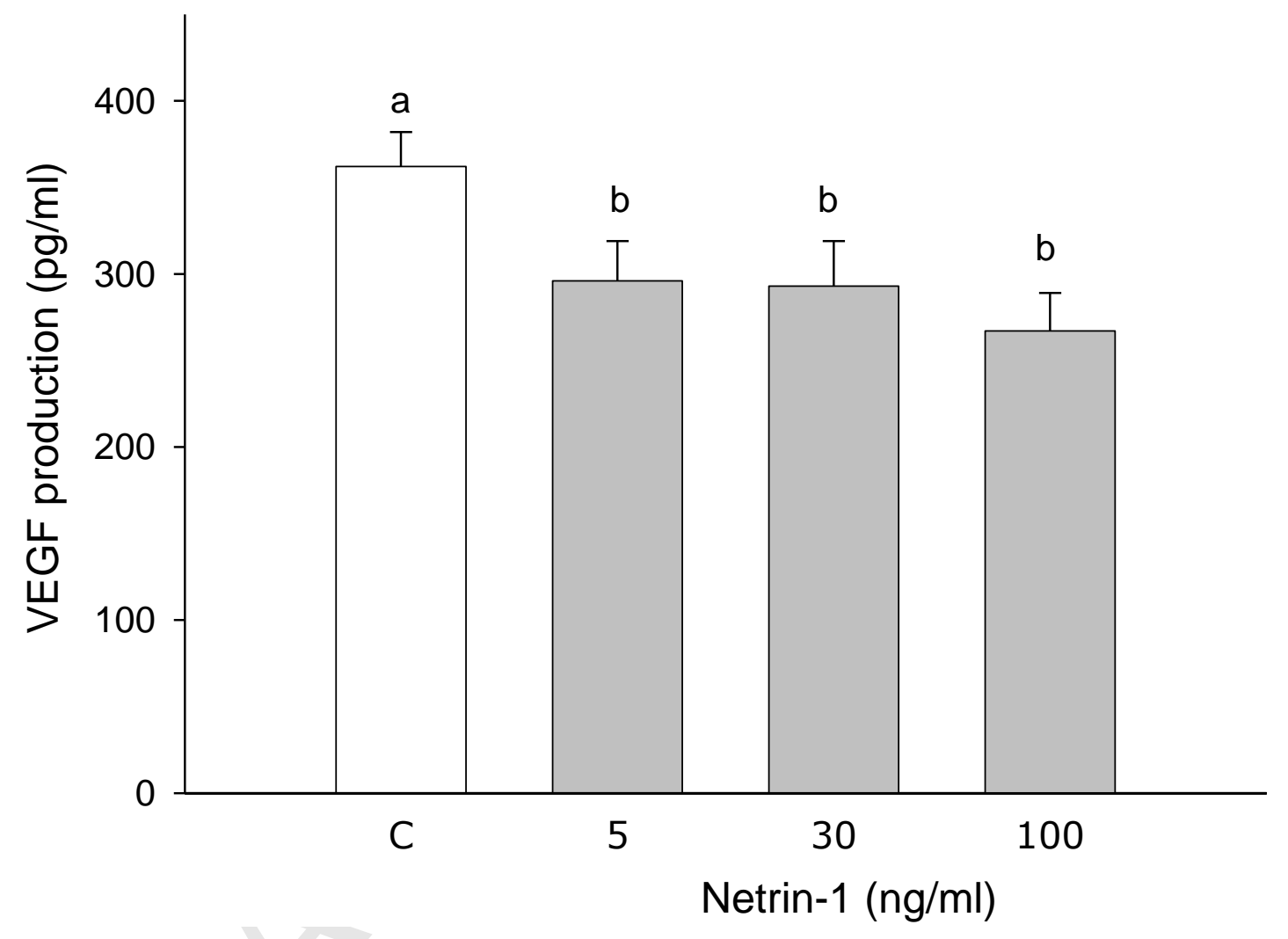


Figure 10

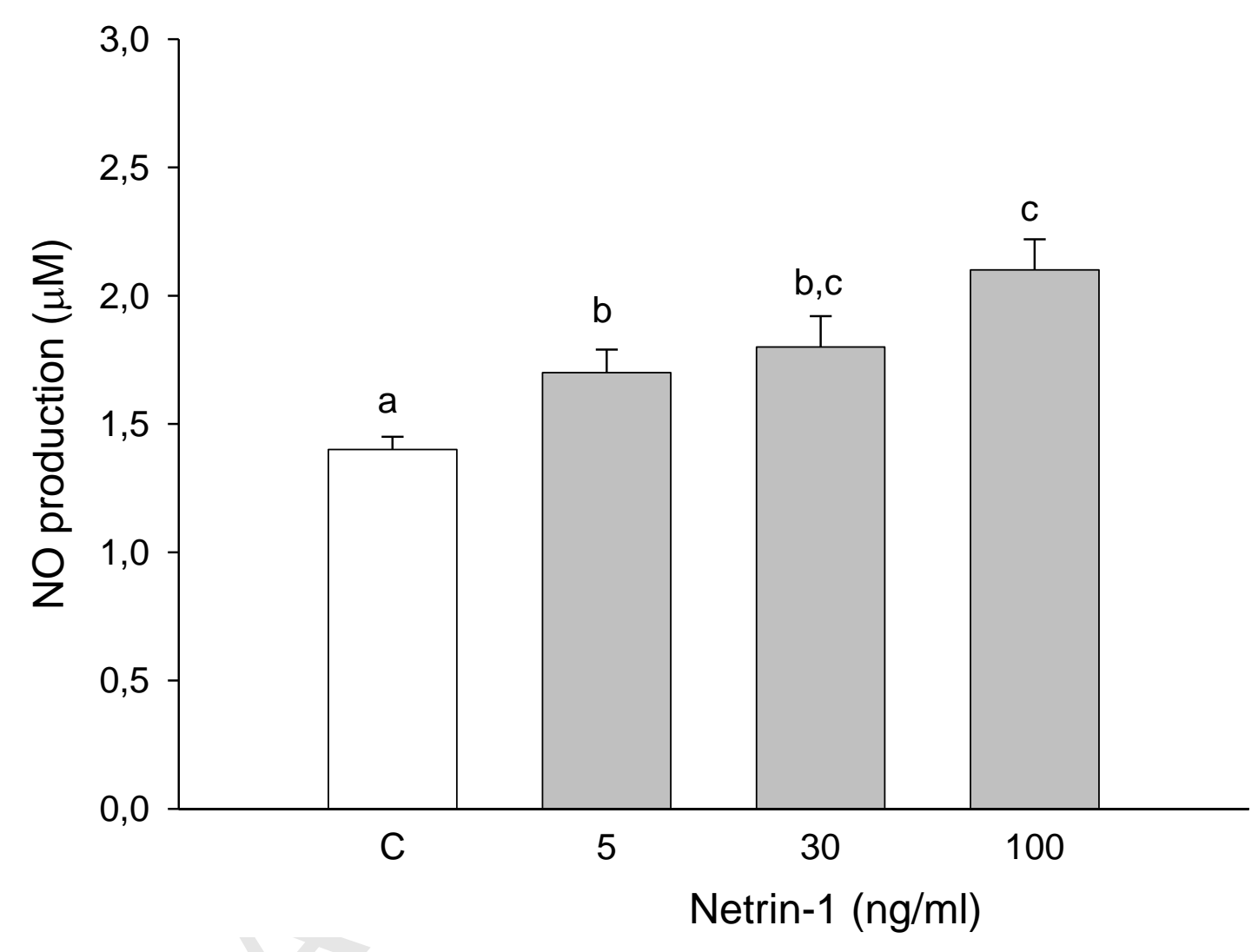

